\title{
Standpunt
}

\section{Die onstuitbare gang van die wetenskap}

Ten einde nie in té vae algemeenhede te verval nie, sal skrywer van hierdie standpunt hom beperk tot die natuurwetenskap, en dan slegs tot enkele terreine binne hierdie bepaalde gebied.

Solank die skeppingsopdrag waar onder andere in Psalm 8 na verwys word, stand hou, sal die mens voortgaan met natuurwetenskaplike navorsing en toepassing. Om te heers in die natuur berus immers op kennis, en laasgenoemde word verkry deur navorsing en die uitbou van die betrokke kennispoel.

Die geskiedenis van die afgelope millennium dui aan dat daar relatief kort periodes, gemeet in dekades, van groot omwenteling plaasgevind het waarna daar redelik gelykmatige, met kleiner skommelings, periodes, gemeet in eeue, verloop het. In die Renaissance van sowat vyf eeue gelede was die hoofdryfvere kuns en godsdiens. Die volgende groot omwenteling, te wete die Industriële Revolusie, is gedra deur die tegnologie en vandag beleef ons die grootste omwenteling van die afgelope millennium, naamlik die kommunikasierevolusie gedra deur die inligtingstegnologie, of anders gestel, die rekenaarswese. Daar is by geleentheid gesê dat die koms van die rekenaar 'n groter impak op die geskiedenis sal uitoefen as die ontdekking en beheer van vuur. Die lys van kommunikasie-instrumente hoef nie hier genoem te word nie. Jou e-posadres het so alledaags geword as jou telefoonnommer. Dit is duidelik dat die ontwikkelde wêreld op hierdie spesifieke gebied 'n utiliteitsfase binnegaan. Laat my illustreer. Tot sowat 'n driekwart eeu gelede was die elektriese motor tog 'n besondere illustrasie van tegnologie gebaseer op die elektromagnetisme. Vandag besit die gewone huishouding 'n dosyn of meer elektriese motors soos gebruik in wasmasjiene, stofsuiers, poleerders, koekmengers, klitsers, ens. Met ander woorde, die elektriese motor het 'n utiliteitsartikel geword waarvan ons skaars bewus is as die elektriese knoppie gedruk word.

Dit is nagenoeg vanselfsprekend dat binne twee dekades vanaf datum die rekenaar in kleiner en groter formaat as onsigbare, alledaagse utiliteitskomponent elke aspek van ons lewe sal penetreer. Hierdie snel groeiende gebruiksveld sal steeds groter eise aan die tegnologie stel. Tans berus alle rekenaartegnologie op wat bekend staan as halfgeleiervastetoestand-mikroëlektronika. Hierdie basis nader nou die eindpunt van sy ontwikkeling en ' $n$ splinternuwe fase is in aanvraag. Dit blyk dat teoretiese denke reeds so ver gevorder is dat so ' $n$ nuwe fase nie meer blote bespiegeling is nie. Die kwantumrekenaar is besig om 'n werklikheid te word. Hierin kan 'n oorgang van een energietoestand na ' $n$ ander in 'n atoom of molekuul ingespan word as 'n skakel of 'n hek vir 'n rekenaar. Dit word beskou dat as 'n aantal elektrone wat as skakels dien, ter sprake is, kan dit effektief soos 'n massiewe aantal rekenaars in parallel gesien word. Die snelheid en berekeningsmag van so 'n "brein" is bokant ons verbeeldingsvermoë. Daar word reeds gedink aan langketting-molekules wat kan dien as plaasvervangers vir geleierdraadjies. Laasgenoemde is juis een van die beperkende faktore in die huidige vastetoestand-tegnologie.

Gesien die uitgebreide navorsingsprogramme wat tans aan die gang is in 'n hele aantal leidende labaratoria oor die wêreld op die gebied van die kwantumrekenaarswese is dit ' $n$ kwessie van dekades voordat die mensdom gekonfronteer sal word met 'n kunsmatige brein wat nagenoeg alle verbeelding te bowe gaan.

'n Ander gebied wat in hierdie kort beperkte oorsig genoem moet word, is vanselfsprekend dié van molekulêre biologie. Ons is almal vertroud met terme soos selle, die DNA-molekuul, chromosome, gene, genome, kloning, ens. Vrae soos: sal die wetenskap oplossings vind vir alle siektes, die verouderingsproses, orgaanproduksie vir oorplanting, en selfs mense maak is aan die orde van die dag.

Gene, die geënkodeerde inligtingsboustene in die DNAmolekuul se manipulasie het reeds tot groot voordele in die landbou gelei. Kloning, waarmee 'n presiese duplikaat van 'n bestaande dier geproduseer kan word, is wêreldwyd bekend. Die toepassing op mense is uiteraard 'n saak van intense debat op etiese sowel as politieke vlak. Hieroor kan eindeloos geredekawel word.

Die nuutste prestasie in molekulêre biologie, die sogenaamde mensgenoom-projek het beslis 'n nuwe fase ingelei, veral in die mediese wetenskap. Kortom, ons weet nou met taamlike presiesheid uit watter boustene en hoe ons saamgestel is. Die onmiddellike voordele sal makliker diagnose en prognose in die medisyne voortbring. Dit beteken egter nie dat genesings oornag sal volg nie. Die situasie kan vergelyk word met die daarstelling van die periodieke tabel van die elemente. Dit het slegs meegebring dat Chemie as wetenskap vinniger en beter kon vorder. Dit was allermins nie 'n afgehandelde vakgebied na Mendeleef se historiese bydrae nie.

Verder sal geassosieerde vraagstukke soos byvoorbeeld assuransiemaatskappye se vereistes volg. Sal so 'n maatskappy se premies nou beïnvloed word deur die potensiële siektes wat die kliënt se genestruktuur openbaar? Voeg hierby die eenvoudige werklikheid, naamlik dat 'n mens se gesondheid en betekenis in die samelewing waarskynlik meer beïnvloed word deur sy leefwyse as sy gene. Vigs is 'n treffende illustrasie hiervan.

Intussen moet ons onsself nie vermoei deur te debatteer of hierdie soort navorsing moet voortgaan of nie. Dit sal eenvoudig voortgaan; net soos atoomkernsplitsing in die vorige eeu.

'n Ander uiters interessante neweproduk van molekulêre biologie sal geskied op die terrein van spesie-ontstaan oor die afgelope drie en 'n half biljoen jaar. Ongeag watter meganisme aanvaar word, te wete kreasionisme of een of ander van die verskeie evolusiemodelle, is dit duidelik dat enige verskil en/of verandering wat wel plaasgevind het tog eventueel op molekulêre vlak uitgeklaar moet word. Die fenemologiese verklaring soos gebaseer op paleontologiese gegewens is net nie genoegsaam nie. Tans kom die paleontologiese en molekulêre benaderings nie bymekaar uit nie. Die laaste woord, indien die wetenskap wel daarby uitkom, sal deur die molekulêre biologie gespreek word.

Verder wil ek kortliks stilstaan by die kosmologie. Dit is net so belangrik om te begryp hoe die groot heelal in wese daar uitsien as wat ons verstaan wat op atomêre vlak gebeur. Ongeag van moontlike praktiese toepassings is dit so nodig vir die mens se gees as brood vir sy liggaam dat ons tog probeer verstaan wat in die sterrehemel aangaan en hoe dit alles moontlik tot stand gekom het. Geen wonder nie dat die wyses van die vroegste 
tye af hulle met hierdie studie besig gehou het. In hierdie bepaalde opsig is die RSA in 'n posisie om 'n betekenisvolle bydrae op internasionale vlak te maak. Ons gunstige klimaat leen sigself tot goeie sterrekundewaarneming.

Die huidige oerknalmodel berus op waarnemings gemaak oor nagenoeg 'n eeu en op Einstein se algemene relatiwiteitsteorie. Tot dusver het daar nog nie betekenisvolle waarnemings of 'n diskreditering van die genoemde teorie na vore getree om die oerknalmodel te kelder of selfs ernstig te bevraagteken nie.

Die woord model moet beklemtoon word. Navorsing op energiedeeltjie-prosesse sal ongelukkig nie die volle verhaal kan demonstreer nie. Die nodige deeltjieversneller wat die prosesse reg aan die begin van die heelal se geskiedenis kan demonstreer, sal so groot en duur moet wees dat die hele mensdom gesamentlik dit nie kan bekostig nie. Uiteraard het teoretiese besinning en bespiegeling nie uitgebly nie. Kwantumkosmologie, waarin die bestaande kwantumteorie oorgedra word na kosmiese afmetings is nou 'n bekende term in die astrofisika. Metings oor die afgelope dekade het weliswaar die toevoeging van bykans misterieuse faktore soos die teenwoordigheid van "donker materie" en "donker energie" meegebring ten einde die oerknalmodel te verbeter.

Soos verwag kan word, speel die betrokke wetenskaplikes se lewens- en wêreldbeskouing hier ' $n$ bepaalde rol. Dat hierdie kenbare heelal toevallig die "regte een", uit 'n oneindige aantal heelalle is, word as een moontlikheid beskou. By die "regte een" word bedoel 'n heelal wat in sy historiese gang eventueel 'n planeet tot stand laat kom soos die aarde, geskik vir die huisvesting van 'n besondere spesie, naamlik die mens. Andersins stel sommige dat dit blote blinde toeval kan wees dat 'n enkele heelal juis die "regte een" is. 'n Derde alternatief is natuurlik dat 'n Skepper dit alles met ongelooflike presisie beplan het. Elk van hierdie moontlikhede is 'n saak van geloof. Nie een sal ooit bewys of teenbewys kan word nie. Trouens, ongeag wat ons lewens- en wêreldbeskouing ook al is, is jou vertrekpunt per definisie 'n geloofstap. Vir hierdie skrywer vereis die moontlikheid dat slegs blinde toeval gelei het tot die huidige wêreld met sy biologiese lewe, té veel geloof. Die boodskap van die Bybel, naamlik dat God dit alles tot stand gebring het, maak veel meer sin indien na al die waarnemings, wat fyn beplanning demonstreer, gekyk word.

'n Slotopmerking. Vir die grootste gedeelte van die vorige eeu was die sogenaamde debat tussen geloof (in godsdienstige $\sin$ ) en wetenskap 'n gesprek wat skynbaar na niks kan lei nie. Dit was gesien as twee wêrelde wat nooit kan verwag om wedersydse aansluiting te vind nie. Vandag is daar 'n toenemende aantal vooraanstaande denkers op albei hierdie terreine wat dit as 'n potensieel vrugbare interaksie beskou. Per slot van rekening, die Geskape Woord (die natuur) en die Geskrewe Woord (die Bybel) het dieselfde Outeur, en hoe meer korrek ons albei lees, hoe meer harmonie kan ons verwag.

\section{Louw Alberts \\ Pretoria}

